\title{
Manajemen Madrasah dalam Pembelajaran Jarak Jauh Melalui Peningkatkan Efektivitas Siswa MAN 1 Sragen
}

\author{
Sri Rokhmiyati \\ IAIN Salatiga, Salatiga, Indonesia \\ rohmyabieta.79@gmail.com
}

\begin{abstract}
This study aims to understand and provide an overview of madrasah management in distance learning through increasing the effectiveness of students in MAN 1 Sragen. The research method used is descriptive qualitative research, through interview and observation techniques to students. The results obtained describe the effectiveness of students through distance learning that can be done with various applications, but learning is quite effective even though it is not optimal because some of the material has to be explained directly. The implication in this research is that the principal as a manager is required to be able to carry out the duties of being a leader in every policy, planning in learning, and managing various components in the madrasah.
\end{abstract}

Keywords: Madrasah Management; Distance Learning; Student Effectiveness

\begin{abstract}
Abstrak
Penelitian ini memiliki tujuan memahami dan memberikan gambaran tentang manajemen madrasah dalam pembelajaran jarak jauh melalui peningkatkan efektivitas siswa MAN 1 Sragen. Metode riset yang digunakan ialah penelitian kualitatif deskriptif, melalui teknik wawancara dan observasi kepada siswa. Hasil yang didapatkan mendeskripsikan efektivitas siswa melalui pembelajaran jarak jauh dapat dilakukan dengan berbagai aplikasi, namun pembelajaran cukup efektif walaupun kurang maksimal karena sebagian materi ada yang harus dijelaskan secara langsung. Implikasi dalam riset ini kepala sekolah sebagai manajer dituntut mampu melaksanakan tugas menjadi pemimpin di setiap kebijakan, perencana dalam pembelajaran, dan mengelola berbagai komponen yang ada di madrasah.
\end{abstract}

Kata kunci: Manajemen Madrasah; Pembelajaran Jarak Jauh; Efektivitas Siswa 


\section{A. Pendahuluan}

Pandemi virus Covid-19 telah mengubah segala rancangan kehidupan masyarakat di semua negara, salah satunya di negara Indonesia. Terhitung sejak bulan Maret 2020 pemerintah Kemendikbud dan Kemenristekdikti mengeluarkan kebijakan khusus (Arenggoasih \& Khatibah, 2020), semua pembelajaran di Indonesia telah melakukan program belajar mengajar dalam jaringan atau pendidikan jarak jauh yang sebelumnya masih dengan tatap muka. Pembelajaran daring merupakan pembelajaran formal yang diselenggarakan oleh setiap instansi sehingga terjadi secara daring sehingga siswa dan guru tidak saling bertemu langsung namun memerlukan telekomunikasi interaktif untuk menghubungkan keduanya (Suni, 2020). Pembelajaran jarak jauh ini merupakan suatu rancangan untuk seluruh siswa supaya bisa melakukan proses pembelajaran dari rumah secara online serta memanfaatkan teknologi informasi. Dalam pembelajaran jarak jauh siswa dapat bergerak dalam waktu singkat dan mengelola informasi dengan daya tampung lebih besar, kemudian dapat melatih dalam hal kedisiplinan dan kemampuan berkoordinasi. Pembelajaran jarak jauh diberlakukan guna antisipasi dan menghentikan menyebarnya virus Covid-19 di Indonesia (Supriatna, 2020), mengingat jumlah kasus yang semakin naik dalam setiap harinya. Hampir semua instansi pendidikan di Indonesia melakukan pembelajaran melalui sistem daring. Sektor-sektor yang ada di Indonesia hampir semua terkena dampak besar dari Covid-19 diantaranya sektor pariwisata, pendidikan, ekonomi, manufaktur, sosial, pangan, transportasi dan lainnya (Susilo dkk., 2020).

Dalam kondisi memerlukan penanganan segera covid-19, manajemen pembelajaran dalam peningkatan keefektifan pembelajaran mempunyai posisi yang sangat urgen, karena kegiatan belajar dituntut untuk tetap menyuguhkan servis yang prima sesuai standar pendidikan dan wajib menuruti protokol kesehatan yang sudah disepekati oleh empat menteri (SKB 4 menteri), sebab perlu penanganan serius dalam penyebaran covid-19 peran guru dalam mengelola pendidikan dan menaikkan efektivitas dalam proses pembelajaran sangat penting (Saifulloh \& Darwis, 2020).

Kemampuan pembelajaran dalam jaringan mayoritas siswa serta guru belum menguasai apalagi bagi siswa ataupun guru yang terletak di wilayah pedalaman. Pendidikan online yakni memanfaatkan koneksi internet di setiap pembelajaran. Proses belajar mengajar jarak jauh untuk guru ataupun peserta didik memiliki kesempatan waktu luas dalam pelaksanaannya. Terdapat pula platform yang dapat digunakan dalam pendidikan jarak jauh diantaranya: google clasroom, google meet, zoom meeting, Group WA dan lainnya. Gikas\&amp;amp; Grant (Firman \& Rahayu, 2020) mengantarkan pembelajaran daring pada pelaksanaannya memerlukan sokongan perangkat mobile semacam android, laptop serta tablet yang dapat dipakai buat mengakses informasi 
kapan dan dimana saja. Korucu\&amp;amp; Alkan (Firman \& Rahayu, 2020) menerangkan konsumsi mobile teknologi mempunyai konstribusi besar dalam dunia pembelajaran, tercantum di dalamnya proses mencapai maksud pendidikan jarak jauh. Bersumber pada masalah di atas, hingga studi ini membahas mengenai efektivitas pembelajaran jarak jauh di masa pandemi covid-19.

Manajemen madrasah merupakan sesuatu proses penerapan program madrasah dengan penyusunan, organisasi, pengawasan, pengolahan, pengarahan serta pengadministrasian madrasah buat mencapai visi yang efisien serta efektif dalam pembelajaran yang sudah ditetapkan. Dalam perihal ini manajer madrasah yang berprofesi sebagai kepala madrasah dituntut sanggup melakukan tugas sebagaimana kedudukan pemimpin tiap kebijakan. Prioritas dari kepala madrasah ialah perencanaan dalam pendidikan mengelola bermacam komponen yang terdapat di madrasah. Manajemen madrasah bisa memberdayakan sumber energi manusia supaya bisa tercapai tujuan dari sekolah (Rokhmiyati, 2018).

Pembelajaran jarak jauh pun menjadi pilihan yang sesuai di era sekarang di masa pandemi. Semua jenjang pembelajaran di Indonesia melaksanakan pembelajan jarak jauh via daring atau online. Pembelajaran jarak jauh ini juga berlaku untuk siswa siswi di MAN 1 Sragen. Sehingga siswa siswi dan guru dapat melakukan kegiatan belajar mengajar via daring dengan menggunakan alat komunikasi seperti handphone maupun laptop masing-masing dengan sebagaimana mestinya.

Berdasarkan penjelasan Waka kurikulum bapak Drs. Khanifudin, bahwa pembelajaran kali ini dinilai kurang efektif karena materi tidak bisa tersampaikan secara utuh muncul berbagai kendala ketersediaan kuota yang cukup memakan biaya tinggi bagi guru maupun siswa yang mengikuti pembelajaran daring ini sedangkan pendapatan guru maupun orang tua ada sebagian yang masih rendah atau kurang mampu. Para siswa juga mengeluhkan kendala pada jaringan internet mereka yang belum stabil karena rumahnya di daerah plosok sehingga krisis sinyal (02/W/21-11-2020).

Daya serap dalam pembelajaran jarak jauh ini menjadi sedikit terganggu bagi beberapa siswa yang kurang jelas dalam penerimaan materi karena pemahaman siswa yang berbeda-beda lalu guru memberikan tugas berakibat para siswa merasa terbebani, bingung, dan malas dalam mengerjakan sehingga tidak tepat waktu pada saat pengumpulan tugas, pernyataan tersebut merupakan keluhan salah satu siswi kelas $\mathrm{X}$ IPA 3 Makrupi Tria Salamah (04/W/23-12-2020). Maka dari itu guru dapat memberi motivasi terhadap siswa siswinya supaya bisa turut belajar dengan efisien.

Peneliti hendak menyampaikan riset terdahulu ataupun kajian terdahulu yang mempunyai keterkaitan guna mendukung keabsahan serta keorisinilan riset. 
Menyertakan penelitian terdahulu dengan tujuan menjelaskan perbedaan dan persamaan serta ada temuan baru dari penelitian saat ini. Bersumber pada penelitian Ahmad Munir (Saifulloh \& Darwis, 2020), Institut Agama Islam Syarifuddin Lumajang Indonesia dengan judul "Manajemen Pembelajaran dalam Meningkatkan Efektivitas Proses Belajar Mengajar di Masa Pandemi Covid-19”. Riset ini fokus pada peran guru dalam pengelolaan pendidikan untuk peningkatan efektivitas pembelajaran yang sesuai. Artinya guru harus dapat mengelola pembelajaran dari planning (perencanaan), organizing (pengorganisasian), actuating (pelaksanaan) dan evaluating (evaluasi) untuk memenuhi pembelajaran efisien dan efektif di waktu proses belajar mengajar jarak jauh,baik secara dalam jaringan (daring) maupun luar jaringan (luring)

Penelitian Abidin dkk., (2020) dari Universitas Indraprasta PGRI Jakarta tentang "Efektivitas Pembelajaran Jarak Jauh Pada Masa Pandemi Covid-19" pengaruh dari pandemi covid-19 sekarang ini memberi sumbangsih signifikan pada dunia pendidikan, dengan menyebarnya covid-19 aktivitas pembelajaran sering dilaksanakan dengan tatap muka berganti melalui pendidikan jarak jauh secara mandiri.

Penelitian ketiga oleh (Wibowo dkk., 2020), Efektivitas pembelajaran Jarak Jauh Pada Mata Kuliah survey dan Pemetaan Sumber Daya Wilayah di Masa Pandemi Coronavirus Disease 2019. Riset tersebut konsentrasi pada mengoptimalkan pendidikan yang dilaksanakan memakai alternatif pilihan platform atau aplikasi guna memperoleh zona nyaman dalam situasi yang sebetulnya tidak sesuai. Pembaharuan dalam pendidikan sangat dibutuhkan pada waktu kedepan guna mendapatkan pendidikan yang berarti dan lifelong learning. Sebaliknya riset yang dilakukan peneliti mendeskripsikan tentang "Manajemen Madrasah dalam Pembelajaran Jarak Jauh Melalui Peningkatkan Efektivitas siswa MAN 1 Sragen”. Sehingga bisa ditarik kesimpulan ada persamaan dengan penelitian sebelumnya terkait pembelajaran jarak jauh, memiliki perbedaan dalam subjek ataupun objek yang diteliti. Memiliki perbaruan tingkatan efektivitas siswa dalam pendidikan Jarak jauh ataupun daring sepanjang masa pandemi covid-19.

Menurut pengamatan penulis, terlihat jelas bahwa ketika pembelajaran jarak jauh diterapkan di sekolah dengan infrastruktur yang kurang memadai, pembelajaran jarak jauh dianggap kurang efektif. Ini karena proses belajar mengajar jarak jauh berdasar teknologi membutuhkan cara mendekati yang berbeda dalam rancangan, penerapan dan penilaian. Penerapan proses belajar mengajar jarak jauh, siswa perlu memberikan atensi khusus, prioritas infrastruktur yang dimanfaatkan, kemampuan motivasi diri dan jaringan internet yang layak sehingga bisa berlangsung pengajaran mandiri. Permasalahan pendidikan jarak jauh antara lain membuat akses internet yang tidak merata, peralatan yang tidak memadai, biaya kuota yang tinggi, pemahaman iptek yang tidak merata oleh pendidik atau guru, persiapan yang kurang memadai untuk 
proses pengajaran dengan cara melakukan pendidikan jarak jauh, serta kesusahan orang tua dalam menemani anak. Aktivitas pengajaran anak jadi masalah yang dialami dalam proses belajar mengajar jarak jauh. Sebagian pemecahan yang disampaikan oleh pemerintah terdapatnya sebagian regulasi yang secara gamblang mengendalikan serta menguraikan penerapan proses pendidikan jarak jauh, semacam Surat Edaran Nomor. 15 Tahun 2020, mengenai peraturan pelaksanaan home learning dalam suasana penyebaran Covid-19, keleluasaan pemakaian dana BOS buat mensubsidi kuota siswa dan guru jadi salah satu kebijaksanaan pemerintah buat menanggulangi tingginya bayaran kuota dalam konteks ini.

Penelitian ini memiliki tujuan untuk memahami dan memberikan gambaran tentang manajemen madrasah dalam pembelajaran jarak jauh melalui peningkatkan efektivitas siswa MAN 1 Sragen. Pembelajaran jarak jauh bagi siswa di MAN 1 Sragen cukup efektif. Mengukur efektivitas dalam penelitian ini dengan indikator keefektivan pembelajaran merupakan tergapainya suatu tujuan pendidikan. Tujuan pendidikan terpenuhi secara optimal hingga bisa dinyatakan pendidikan menggapai keefektivitasannya. Selain itu, keikutsertaan aktivitas siswa menampilkan efisiensi pendidikan. Uraian siswa dalam menjajaki pendidikan jarak jauh ialah pembelajaran mampu menjalankan tugas dengan tepat dan cermat jika pendidikan tersebut bisa menggapai tujuan yang diinginkan dan siswa bisa memahami modul pelajaran serta menerapkannya.

Jadi penelitian ini mempunyai maksud untuk memperoleh pengetahuan umum kepada realita sosial dari sudut pandang partisipan. Pengetahuan didapat sesudah mengerjakan analisa terhadap realita sosial dan diambil simpulan berupa pengetahuan umum mengenai fakta tersebut. Penelitian kualitatif ini dipilih untuk terjun langsung sehingga peneliti dapat mencari tahu bagaimana kemandirian siswa MAN 1 Sragen dalam melaksanakan pembelajaran jarak jauh.

Teknik pengumpulan data menggunakan wawancara yang merupakan pembicaraan yang memiliki tujuan, seperti halnya sebuah percakapan yang terjadi dua pihak, yakni dengan cara memberikan pertanyaan dan mendapatkan jawaban dari pertanyaan itu. Dalam riset ini interview melalui kepala madrasah, waka kurikulum, guru dan beberapa siswa. Interview ialah salah satu teknik akumulasi data cara melakukan survei dengan menyampaikan pertanyaan yang akan sampaikan secara lisan kepada subjek yaitu dengan siswa MAN 1 Sragen sebagai narasumber. Sehingga penelitian perlu menjelaskan dan membutuhkan kurun waktu lumayan lama untuk meyelesaikan riset sesuai waktu. Teknik wawancara bisa dilaksanakan melalui pertemuan langsung atau tatap muka dan melalui pesan suara seperti telephone dan voice note. Metode riset yang digunakan oleh peneliti merupakan metode kualitatif yang 
bersifat deskriptif maksudnya riset mengacu kepada metode akumulasi informasi yang dilaksanakan dengan interview mendalam melalui informen dan key informen. Datadata yang disajikan berbentuk riset kualitatif berbentuk kata-kata bukan berbentuk angka-angka. Informasi tersebut wajib berbentuk kata-kata tertulis yang bisa mendeskripsikan dan menguraikan secara terperinci hasil dari riset ataupun wawancara mendalam tersebut. Analisis yang digunakan dalam riset ini menekankan pada bagaimana efektivitas pengajaran jarak jauh di era pandemi covid-19.

Penelitian ini dilaksanakan di MAN 1 Sragen, berlokasi di Jl. Irian No.5, Nglorog, Kecamatan Sragen, Kabupaten Sragen, Jawa Tengah. Bagi penulis memilih penelitian di lokasi tersebut yakni MAN 1 Sragen karena manajemen sekolah mengambil gerak cepat serta koordinasi yang baik dengan segenap bagian madrasah, hingga proses pendidikan serta pengajaran saat masa wabah Covid-19 tetap berjalan lancar. Terdapatnya ketetapan yang mengharuskan guru serta siswa melaksanakan pendidikan dari rumah hingga kepala madrasah sanggup memberikan semangat perbaruan pada siswa, guru serta orangtua dengan cekatan dan cermat.

Dalam pengumpulan materi yang dibutuhkan dengan menggunakan metode pengamatan partisipatif pasif, penelitian hadir dilokasi aktivitas orang yang diobservasi, namun tidak turut serta pada aktivitas tersebut. Dalam riset ini peneliti memakai teknik akumulasi data dengan pengamatan partisipasi aktif. Selain itu dengan dokumentasi yang merupakan suatu teknik pengumpulan data melalui cara pengambilan gambar dalam suatu situasi. Dokumentasi data dan informasi yang diperlukan dalam penelitian guna membantu dalam pengerjaan hasil dan bukti yang akurat guna tercapainya proses penelitian pembelajaran jarak jauh.

\section{B. Pembahasan}

\section{Manajemen Madrasah dalam pembelajaran Jarak Jauh}

Penafsiran efektivitas Pendidikan Bagi Miarso (2015) efektivitas pendidikan ialah satu diantaranya standar kualitas pembelajaran serta kerap kali dinilai melalui ketercapaian tujuan, ataupun bisa pula dimaknai selaku kesesuaian dalam pengelolaan sesuatu suasana "doing the right things". Pendidikan yang efisien merupakan pembelajaran yang memfasilitasi peluang belajar mandiri ataupun melaksanakan kegiatan sebanyak-banyaknya pada peserta didik buat belajar (Rahmawati, 2016). Sebaliknya Sadiman (1987) mengatakan efektivitas pendidikan merupakan hasil manfaat yang didapatkan sehabis penerapan pengajaran (Tabany, 2017). Bersumber pada penafsiran di atas bisa ditarik kesimpulan kalau efektivitas pendidikan merupakan satu standar kualitas pembelajaran serta kerap kali di evaluasi melalui ketercapaian 
tujuan, yang didapatkan seusai penerapan pengajaran, yang disediakan peluang belajar mandiri ataupun melaksanakan kegiatan seluas-luasnya pada peserta didik buat belajar.

Pendidikan Jarak Jauh ialah proses belajar mengajar yang menitik beratkan kepada tata cara belajar sendiri (self study). Belajar sendiri disatukan dalam kerjasama dengan berurutan dalam menyediakan modul pendidikan, memberikan tutorial pada peserta didik, serta pengawasan terhadap kesuksesan pengajaran. Pendidikan jarak jauh merupakan kala proses pendidikan tidak terbentuknya kontak dalam wujud bertemu langsung antara pembelajar dan pengajar (Munir, 2012). Komunikasi terjadi dua arah yang dihubungkan melalui media semacam pc, tv, video, telefon, internet, radio dan lainnya (Rokhmiyati, 2020). Kearsly mengemukakan kalau pendidikan jarak jauh merupakan belajar yang dirancang di luar tempat memberi pelajaran ataupun tempat lain (Yerusalem dkk., 2015). Oleh sebab itu, bagi (Sutiah, 2018) dibutuhkan pengetahuan spesial dalam merancang modul pendidikan, strategi-strategi khas pendidikan, metodologi yang sesuai dalam komunikasi lewat bermacam-macam media, serta penyusunan administrasi dan organisasi yang khusus pula.

Pendidikan jarak jauh ialah pelatihan yang disampaikan pada partisipan ataupun siswa yang tidak berkerumun di satu tempat secara teratur buat memperoleh pelajaran secara langsung dari narasumber. Instruksi dan bahan terinci yang spesial disediakan ataupun dikirimkan buat para partisipan yang berikutnya melakukan tugas-tugas yang dilakukan evaluasi oleh narasumber. Dalam realitasnya bisa kemungkinan narasumber dan partisipan tersebut berjarak tidak cuma secara geografis tetapi waktu pula. Pada penerapannya terdapat sebagian aspek berarti yang wajib dicermati, supaya sistem pembelajaran (pendidikan) jarak jauh bisa berjalan dengan baik, ialah atensi, yakin diri pendidik, pengalaman, gampang memakai perlengkapan, kreatif memakai perlengkapan, serta menjalankan interaksi dengan peserta didik (Prawiyogi dkk., 2020).

Bersumber pada penafsiran diatas bisa disimpulkan kalau pendidikan jarak jauh merupakan pembelajaran yang didesain diluar tempat melakukan pembelajaran maupun di tempat lain serta proses pendidikan tidak terjalin tatap muka langsung antara pembelajar dan pengajar. Sehingga pendidikan menitik beratkan kepada belajar sendiri (self study), serta memakai strategi-strategi tertentu dalam merancang modul pendidikan semacam penyusunan administrasi, organisasi serta metodologi komunikasi lewat bermacam-macam media.

Dilakukannya Learning Form Home setiap guru melakukan modifikasi cara penyampaian setiap pembelajaran dengan cara daring melalui website, zoom, dan WhatshApp. Berbagai upaya dilakukan oleh guru walaupun ada kendala tetapi bisa teratasi (Santani, 2020). Pemakaian teknologi mobile memiliki konstribusi pada institusi 
kependidikan, diantaranya ialah penggapaian maksud pendidikan jarak jauh. Pemanfaatan platform WhatsApp ini masih digunakan dikarenakan terkadang siswa terkendala saat hendak login ke e-learning dan kuota terbatas hanya aplikasi WhatsApp saja yang masih bisa diakses. Sehingga aktivitas pembelajaran mulai dari pembuka, presensi kehadiran melalui chat grup kelas melalui WhatsApp, lalu guru memberikan link materi yang telah diunggah ke Google Drive. Guru juga menjelaskan materi digrup tersebut, serta penugasan menggunakan platform google formulir. Akan tetapi bagi siswa yang dapat login ke e-learning tersebut mereka presensi dan mengakses link materi, serta mengerjakan penugasan di platform tersebut. Berbagai macam media bisa dimanfaatkan guna memberikan dukungan penerapan pendidikan online, seperti kelas virtual memakai layanan WhatsApp dan Google Classroom.

Berkenaan dengan pendidikan jarak jauh ini maka banyak faktor yang bisa menjadi penghambat terlaksananya, diantaranya adalah tidak meratanya teknologi yang dimiliki antara madrasah unggulan dengan madrasah non unggulan, atau madrasah negeri atau madrasah swasta. Belum lagi kompetensi guru sebagai pengguna aplikasiaplikasi pembelajaran berbasis online yang belum memadai, termasuk juga keterbatasan ekonomi untuk pembelian kuota internet, keterbatasan sarana dan prasana pendukung telaksananya pembelajaran daring atau pembelajaran jarak jauh (Muhaemin \& Mubarok, 2020).

Guna tingkatkan kapasitas dan mutu guru, Dinas Pendidikan Kabupaten Sragen sudah melaksanakan kerja sama dengan provider buat melaksanakan pelatihan pemakaian iptek dalam rangka pendidikan jarak jauh, walaupun melalui kuota terbatas, tetapi perihal tersebut ialah satu diantara langkah-langkah yang butuh dalam usaha menaikkan kapasitas guru.

Lingkup pengajaran dan pendidikan meliputi situasi dan kondisi yang sangat menyatu. Tidak hanya melibatkan siswa maupun guru. Berbagai faktor yang menentukan kesuksesan pembelajaran tidak hanya berkaitan dengan kehidupan sekolah. Dinamika kehidupan di luar madrasah juga sangat menentukan, dan keadaannya selalu berganti. Apalagi dalam situasi pandemi seperti ini, pendidikan menjadi lebih rumit sebab dilakukan secara online (Hamidaturrohmah, Tri Mulyani, 2020).

Kedudukan kepala madrasah dalam mendesak tenaga pendidik serta tenaga kependidikan buat menguasai ilmu pengetahuan di masa pendemi seperti sekarang diantara satu faktor urgen dalam penerapan pembelajaran jarak jauh. Terdapatnya kebijaksanaan memberikan pelatihan lewat workshop maupun webinar mengenai pengajaran untuk pendidik serta tenaga kependidikan bisa tingkatkan mutu lembaga pembelajaran tersebut dalam membagikan layanan untuk partisipan. 
Dalam penerapan pembelajaran jarak jauh diperlukan kerjasama serta saling berkoordinasi dengan solid antara bagian guru, orang tua, madrasah serta siswa itu sendiri buat lebih mengoptimalkan kesuksesan pelaksanaan pembelajaran jarak jauh tersebut. Dalam keadaan semacam saat ini ini silih menunjang serta silih menegaskan merupakan opsi terbaik buat mendapatkan hasil yang diinginkan dapat terwujud oleh siswa. Bukan cuma siswa kebanyakan dalam penggunaam aplikasi semacam $E$ Learning madrasah ini, tetapi guru juga harus banyak belajar serta menyesuaikan diri dalam mengeksplor bermacam fitur yang dapat digunakan dalam E-Learning madrasah (Shofaul Hikmah, 2020).

Bersumber pada interview bersama bapak H. Sumiran, S. Pd., M.Pd sebagai kepala madrasah MAN 1 Sragen menerangkan kerja sama yang dicoba antara pihak madrasah dengan provider buat meningkatkan layanan internet di madrasah ialah satu diantara usaha memecahkan permasalahan mengenai terbatasnya fasilitas serta prasarana penyokong iptek di madrasah buat menaikkan kualitas. Artinya kedudukan kepala madrasah dalam menjalakan kerja sama dengan provider dalam proses pelayanan memberikan subsidi kuota jadi dorongan yang bisa meringankan orang tua serta siswa itu sendiri (01/W/21-09-2020).

Kepala madrasah smempunyai kewajiban menanggung pengelolaan madrasah dalam setiap keadaan. Kepala madrasah wajib berinisiatif dalam keadaan apapun dan mengawal proses kepemimpinan tetap berjalan meskipun dalam keadaan darurat. Maka dibutuhkan optimalisasi peran kepala madrasah menjadi manajer risiko untuk mengurangi atau meminimalisir akibat pandemi Covid-19 yang dirasakan oleh siswa, guru dan stakeholders secara keseluruhan (Irwanto \& Zainal Arifin, 2020).

Perihal dampingan orang tua sepanjang pendidikan jarak jauh, memanglah dibutuhkan. komitmen dari orang tua supaya bersedia mengosongkan waktu buat menemani anak didik kala melakukan aktivitas pendidikan. Melaksanakan pengawasan dengan meminta agenda proses pendidikan pada anak, ikut melaksanakan proses koreksi tugas yang dikerjakan. Mengosongkan waktu merupakan satu diantaranya kunci dalam mendampingi anak didik sepanjang proses pendidikan jarak jauh.

\section{Meningkatkan Efektivitas Pembelajaran Jarak Jauh (Daring)}

Pemanfaatan media dalam pembelajaran, penggunaan peralatan belajar dalam pengajaran dapat memotivasi minat dan harapan baru, menumbuhkan dorongan dan keinginan aktivitas pembelajaran, dan lebih-lebih mempengaruhi secara psikis pada pembelajar. Pemanfaatan peralatan belajar pada tahap orientasi belajar mengajar sangat berperan membantu efektivitas proses belajar mengajar dan transfer isi dan pesan 
pelajaran pada waktu itu (Falahudin, 2014). Salah satu unsur dalam pengajaran, media tidak pernah selesai dari pembahasan metode belajar secara komprehensif.

Penggunaan media semestinya membentuk aspek yang harus memperoleh prioritas pembelajaran di setiap aktivitas belajar. Tetapi realitanya komponen ini masih jauh dari harapan. Dasar yang menjadi alasan yakni: tidak ada fasilitas biaya, kesulitan mendapat media yang tepat, dan deadline dalam membuat persiapan mengajar terlalu singkat dan lainnya (Nuriansyah, 2020). Sebetulnya tak berguna berlangsung dalam tiap pembelajaran sudah menyiapkan diri dengan ketrampilan dan pengetahuan dalam perangkat belajar mengajar. Menurut Subroto (2014) sebenarnya banyak pilihan media yang dapat digunakan dalam proses pengajaran secara variatif, fasilitas tersebut dimanfaatkan dan dikembangkan sesuai dengan situasi, biaya, waktu ataupun tujuan belajar mengajar yang diinginkan. Setiap bentuk perangkat mempunyai ciri khas pasti yang penting kita ketahui, dengan begitu bisa memberikan alternatif pilihan media yang tepat berdasarkan keperluan dan situasi di lapangan (Manaf, 2015).

Seperti pernyataan yang disampaikan bapak H. Sumiran, S.Pd., M.Pd sebagai kepala madrasah MAN 1 Sragen yakni Guru dapat menugaskan seluruh siswa agar efektif dan menyenangkan dalam mengikuti pembelajaran walaupun di rumah masingmasing. Untuk itu penting bagi siswa dalam mempersiapkan dirinya agar proses pembelajaran jarak jauh yang dilakukan di rumah dapat berjalan efektif maka dan tidak mudah bosan. Pembelajaran dapat efektif apabila mampu memberikan sebuah pengalaman yang baru untuk siswa sehingga dapat membentuk kompetensi untuk siswa dan mengantarkan mereka untuk meraih cita-cita yang telah di impikan secara maksimal (01/W/21-11-2020).

Sistem pendidikan jarak jauh dikala ini bagi pengamatan penulis kurang lebih 4 bulan di MAN 1 Sragen masih jadi tanggung jawab berat untuk para siswa, guru dan orang tua. Pemerintah butuh mencermati keadaan ekonomi para orang tua serta siswa yang terdampak pandemi Covid-19 apabila sistem pendidikan jarak jauh masih jadi opsi, Sistem pendidikan jarak jauh yang dilakukan dalam sebagian bulan terakhir ini bagi penulis belum sepenuhnya efektif.

Menurut satu diantara siswa kelas XII MAN 1 Sragen, Siwi Nurrohmah mengatakan bahwa selama pembelajaran jarak jauh atau daring, siswa mengalami banyak kendala. Bukan hanya masalah tidak mempunyai android ataupun kuota dan signal, namun juga kendala pada pemikiran dan pemahaman siswa mengenai materi yang di sampaikan. Selain itu juga siswa merasa kesulitan dalam belajar jarak jauh, utamanya kelas XII yang tidak lama lagi akan menjalankan kegiatan ujian nasional (05/W/23-12-2020). 
Guna penilaian secara komprehensif butuh dilakukan pengelolaan kepentingan, dari komite sekolah, orang tua, tokoh warga, segenap sekolah dan Dinas Pendidikan diusahakan supaya mutu pembelajaran tidak merosot. Sebab pembelajaran merupakan investasi jangka panjang untuk suatu bangsa terkait dengan masa depan.

Solusi berdasarkan permasalahan ini yakni pemangku kebijakan harus memberikan kebijaksanaan melalui layanan aplikasi gratis kerjasama aplikasi dengan pihak provider internet guna memudahkan pengajaran online. Pemerintah wajib merencanakan silabus proses belajar mengajar dan kurikulum secara online. Untuk sekolah perlu melakukan sosialisasi tata cara atau bimbingan teknik daring proses aplikasi online serta melaksanakan sosialisasi pada siswa dan orangtua lewat media sosial dan cetak mengenai metode penerapan pembelajaran online, relevansi peran dan pekerjaan yang dibebankan.

Pembelajaran online, urgen untuk diselipkan pesan edukatif pada siswa dan orang tua, mengenai pandemi Covid-19. Maka diperoleh pembelajaran yang sama dengan bertatap muka tetapi melalui daring. Pengaruhnya cukup baik, tercapai capaian pembelajaran dan programnya sesuai target,. Ada pembelajaran yang bisa diambil dari dunia pengajaran di era penyebaran Covid-19 yaitu aktivitas pembelajaran offline dengan pendidik buktinya efektif diimbangkan dengan online atau dalam jaringan. Perihal tersebut uraikan oleh satu diantara guru Bahasa Indonesia di MAN 1 Sragen ialah Ibu Muslimah, senin (03/W/09-11-2020).

Baginya pendidikan penuh dengan online, belakangan banyak bermunculan keluhan dari siswa atau orang tua. Beberapa pendidik di madrasah membenarkan apabila pendidikan daring tidak begitu efektif dibanding aktivitas pendidikan offline atau konvensional, sebab sebagian materi harus disampaikan dengan lengkap dan langsung. Selain modul yang di sampaikan melalui daring belum tentu dapat dimengerti seluruh siswa.. Berlandaskan pada pengalaman memberi pengajaran melalui daring, sistem ini efektif guna memberikan tugas, dan kemungkinan hasil dari pekerjaan tersebut disampaikan ketika peserta didik mulai aktif, maka dimungkinkan tugas akan menjadi numpuk.

Mengobservasi yang pernah dialami beberapa guru, wajib juga menyiapkan pemakaian teknologi tepat di era perkembangan seperti sekarang ini. Guru memiliki strategi pengajaran dan berkreasi model yang cocok dengan karakteristik peserta didik di madrasah. Pemanfaatan beberapa aplikasi saat proses belajar mengajar online meringankan guru dalam proses pengajaran. Guru wajib membiasakan memberi pengajaran menggunakan media online di lingkungan yang di siapkan dengan efisien, gampang diakses serta dimengerti siswa. 
Kesuksesan pendidik dalam menjalankan pengajaran online saat kondisi penyebaran Covid-19 menjadikan kapabilitas pendidik dalam inovasi perencanaan, dan mengumpulkan bahan-bahan yang diperlukan modul, tata cara proses belajar mengajar, serta aplikasi yang tepat dengan metode dan materinya. Memiliki kemampuan untuk menciptakan adalah kunci sukses pendidik dalam memberikan motivasi siswa dengan semangat dalam pembelajaran daring tidak membuat terbebani secara psikologis (Wibowo dkk., 2020).

Selain itu, keberhasilan pendidikan online pada masa Covid-19 bergantung kepada kedisiplinan seluruh pihak. Maka sebab itu, segenap madrasah butuh membikin kerangka melalui penyusunan manajemen yang unggul dalam mengendalikan sistem pendidikan online. Pelaksanakan agenda yang runtut, sederhana dan terstruktur guna memudahkan komunikasi sekolah dengan orang tua supaya anaknya melakukan pembelajaran di rumah bisa dilakukan pengawasan dengan efektif.

Maka dari itu pembelajaran online menjadi pemecahan masalah yang efektif dalam proses belajar mengajar di rumah untuk menghentikan penyebaran Covid-19, menjaga jarak (physical distancing) jadi pertimbangan pilihan pendidikan tersebut. Bekerjasama yang baik dengan pihak madrasah baik guru, siswa dan orang tua sebagai aspek yang menentukan agar pengajaran online lebih berdaya guna.

Hambatan pengajaran online sebagai hambatan ataupun kendala awal yakni keadaan orang tua yang mayoritas memakai aplikasi WA. Hambatan kedua yaitu kesusahan memperoleh koneksi internet dan android kerap digunakan orang tua beraktivitas. Aplikasi WhatsApp pula lebih gampang sebab siswa banyak memakai serta dapat memanfaatkannya. Bersumber pada hasil interview keberlanjutan dengan bapak Khanifudin selaku Waka kurikulum terkait pendidikan daring bahwa guru yang memakai pengajaran model online, melaporkan kalau model online tersebut sangat sesuai buat para siswa. Saat pertama pembelajaran online, modul sekedar disampaikan lewat Microsoft Word setelah itu siswa membaca, sampai lambat laun peserta didik merasakan kebosanan. Kala guru memberikan pengajaran online lewat video, peserta didik sangat bersemangat dalam menjajaki pembelajaran. Terlebih apabila menyelesaikan pelatihan soal berbentuk kuis lewat Google Forms, peserta didik sangat bersemangat sebab mereka dapat menyaksikan langsung jawaban yang benar serta pula mereka bisa menyaksikan skor langsung ataupun hasil dari pengerjaannya. Zoom Meeting cuma beberapa kali dilakukan sebab tidak seluruh peserta didik bisa mengakses, terdapat sebagian peserta didik terhalang sinyal. pengajaran online dalam penerapannya mempunyai beberapa kendala (02/W/21-11- 2020). 
Kendala awal, terdapat sebagian siswa tidak mempunyai android, kendala yang kedua yaitu mempunyai android namun terhalang koneksi internet dan sarana, terkendala pengumpulan tugas sebab sinyal sulit. Apalagi informasi lanjutan menarangkan kalau buat sebagian siswa tidak memiliki android sendiri, sehingga wajib meminjam. Kendala ketiga ialah orang tua mempunyai android namun berkegiatan seharian di luar rumah sehingga orang tua sekedar bisa menemani kala malam hari. Kendala keempat yakni terbatasnya jaringan internet, sebagian siswa tidak memiliki android dan koneksi internet kurang mendukung. kendala keempat, tidak seluruh siswa mempunyai sarana android serta terdapat sebagian orang tua yang kurang mengerti teknologi (Kurniasari dkk., 2020).

Perihal ini menimbulkan orang tua susah buat menemani serta memberikan sarana prasarana siswa. Permasalahan semacam ini sangat membatasi dan guru wajib mereview pemberitahuan. Kendala keenam adalah informasi tidak senantiasa langsung diterima orang tua siswa sebab terbatasnya kuota internet. Seperti hari ini terdapat tugas, tetapi 3 hari setelah itu baru dapat membuka WhatsApp. Apalagi pada pertama pembelajaran online peserta didik belum dapat membuka file WhatsApp website sebab belum mempunyai pemahaman terkait aplikasi tersebut. kendala Ketujuh yaitu fitur android dengan keterbatasan, hambatan pada kuota internet dan sinyal. Hambatan awal yakni secara teknis tidak seluruh orang tua siswa mempunyai sarana android. Tidak hanya itu, peserta didik banyak yang menghadapi kebosanan dan kejenuhan belajar melalui online hingga kadang menanggapi soal dengan asal. Motivasi dan fokus peserta didik belajar di madrasah dan rumah pasti berbeda.

Kendala kedelapan yakni android yang digunakan buat mengumpul tugas ialah android kepunyaan orang tuanya, hingga siswa baru bisa menyerahkan tugas sehabis orang tuanya kembali bekerja. Apalagi terdapat sebagian siswa yang tidak dapat menyerahkan tugas. Gambar tugas yang dikirim ke WhatsApp pula kadang tidak jelas, sampai menyusahkan guru buat koreksi. Kendala kesepuluh yaitu dalam pengawasan perilaku jujur peserta didik dalam mengerjakan penilaian sebab tidak dapat tatap muka dengan kawan ataupun tutor. Sepanjang proses belajar mengajar online menghadapi sebagian hambatan, apabila peserta didik merasa bosan, guru wajib berpikir teknik dan strategi dengan triknya bagaimana biar peserta didik dapat keluar dari zona kebosanan. Guru wajib memiliki kreatifitas dalam menghasilkan pengajaran online yang menarik untuk siswa. Serta kadangkala orang tua berkeluh kesah tidak dapat menarangkan dengan rinci pada siswa. Peserta didik kadangkala pula tidak mengikuti saat diajari guru di madrasah. Peserta didik lebih gampang apabila dipaparkan oleh guru di madrasah. Orang tua kerap tidaksabar dalam menemaninya. 
Bagi diantara siswi yang bernama Makrufi Tria Salamah permasalahan sinyal. Kadangkala terdapat sebagian siswa yang mengeluh belum dapat menyampaikan tugas sebab terhambat sinyal. Kendala keempat ialah kadangkala dampingan orang tua tidak maksimal sebab beraktivitas dari pagi hingga sore. Maka kesempatan waktu buat menemani peserta didik menyelesaikan tugas-tugasnya cuma dikala malam hari (04/W/02-12-2020).

Apabila siswa telat berikan reaksi tugas, sedangkan guru wajib lekas mengakumulasi skor maka terjadi ketidaksesuaian waktu dalam pengiriman tugas. Peserta didik dapat menyelesaikan tugas kala orang tua telah di rumah. Saat melakukan teleconfrence lewat zoom meeting kadangkala terhalang sinyal yang tidak lancar. Dialog lewat Google Classroom kadang jaringan ataupun sinyal jadi hambatan dalam pengiriman tugas. Guru tidak dapat mengawasi langsung sekedar dapat menerima produknya saja. Perihal ini menimbulkan dasar dari proses belajar mengajar yang memprioritaskan proses tidak bisa terpantau oleh guru. Produk ialah satu diantara perihal yang dapat diamati oleh guru. Kelebihan dalam pengajaran online ialah lebih santai dan praktis. Instan sebab bisa membagikan tugas tiap saat serta laporan tugas tiap kala, fleksibel dapat laksanakan dimanapun dan kapanpun. Pengajaran online menimbulkan waktu yang mudah diatur untuk orang tua yang memiliki kegiatan di luar rumah serta dapat membiasakan peluang buat menemani putra putrinya belajar. Hemat waktu dan bisa dilaksanakan kapan dan dimana saja, seluruh peserta didik bisa mengakses dengan gampang, maksudnya bisa dicoba dimana saja.

Dilansir dari statment Siwi Nurrohmah yang merupakan siswi berprestasi di MAN 1 Sragen menyampaian bahwa data informasi lebih kilat serta dapat mengakses banyak siswa melalui Group WhatsApp. Lebih instan dan menggampangkan dalam mengambil nilai pengetahuan paling utama apabila mengenakan Google Form. Apabila memakai Google Form, nilai dapat dilihat secara langsung sehingga peserta didik menjadi bersemangat menyelesaikan tugasnya. Tidak hanya itu siswa pula digampangkan dalam pengerjaannya. Siswa tinggal memilah opsi jawaban yang dikira betul dengan meng-klik opsi jawaban yang dimengerti (05/W/23-12-2020).

Kelebihan lain dari pendidikan jarak jauh yakni peserta didik dapat diamati dan ditemani oleh tiap-tiap orang tua. Siswa dan guru mendapatkan pengalaman baru mengenai pembelajaran online. Kedudukan orang tua dalam menemani peserta didik lebih banyak. Namun terdapat pula kekurangan dalam pembelajaran online ialah kurang optimal melibatkan siswa. Pelibatan peserta didik yang diartikan bisa dipantau dari hasil pelibatan peserta didik dalam menjajaki pembelajaran online dengan penuh dari pertama pengajaran hingga akhir pembelajaran. 
Madrasah Aliyah Negara 1 Sragen (MAN) ialah lembaga di jenjang menengah keatas pendidikan resmi di Indonesia yang sederajat dengan Sekolah Menengah Umum (SMU), kurikulum yang terdapat di Madrasah Aliyah mempunyai kesamaan dengan Sekolah Menengah Umum, akan tetapi kurikulum di Madrasah Aliyah ini lebih menonjolkan dalam Pendidikan Agama Islam, tidak hanya itu mata pelajaran universal di Madrasah Aliyah pula ditambah dengan pelajaran agama semacam: Bahasa Arab, Fiqih, akidah Akhlak, Sejarah Kebudayaan Islam dan Qur'an Hadits,. Madrasah Aliyah ini dalam manajemennya dilaksanakan oleh Kementrian Agama, pendidikan Madrasah Aliyah diselesaikan sampai kurun waktu 3 tahun sama dengan sekolah umum, sehabis lulus dapat melanjutkan ke jenjang perguruan tinggi, kursus dan bekerja.

Peneliti memberikan pertanyaan kepada siswi MAN 1 Sragen yang bernama Shintya Febri, Apakah telah cukup efektif pendidikan jarak jauh untuk siswa Madrasah Aliyah Negara 1 Sragen? Keefektifan siswa dalam pembelajaran jarak jauh ini kurang efektif sebab butuh belajar sendiri sehingga dampak negatif timbul terhadap pembelajaran daring antara lain kemalasan saat belajar, sebab terhambatnya akses jaringan pada tiap-tiap wilayah yang kurang normal koneksi internetnya pada saat pembelajaran jarak jauh ini sehingga menimbulkan penurunan dalam pencapaian belajar. Efek tersebut juga bisa mempengaruhi pada handphone menjadi mudah ngehang (berhenti bekerja) bahkan kemarin sempat eror sampai mati sendiri bisa jadi karena kelamaan dipakai buat belajar. Kondisi semacam ini dibutuhkan kesabaran yang ekstra. Belum lagi harus mendownload aplikasi ataupun platform berbagai macam pembelajaran yang digunakan sebagai kelas online yang memakan ruang banyak, misalnya aplikasi zoom metting yang memakan kuota yang besar, sehingga boros di kuota yang harus senantiasa beli. Bahkan bantuan dari pemerintah tidak selalu bisa digunakan untuk belajar daring (06/W/08-12-2020).

Setelah itu dengan pertanyaan yang sama peneliti mencoba mempertanyakan kepada siswa lain yang bernama Nurul Huda, hingga jawabannya: Terdapat sebagian yang berkata keefektifan siswa dikala pengajaran jarak jauh ini telah lumayan efektif dari segi apapun sebab terfasilitasi WiFi dengan kecepatan tinggi sehingga aman-aman saja buat mengakses bermacam platform untuk belajar daring sepanjang masa pandemi ini. Dengan begitu bisa menaikkan semangat belajar. Tetapi kadangkala hambatan jaringan yang eror tidak kunjung normal dan menyebabkan tertundanya pengerjaan tugas ditambah emosi. Dampak positif dari pandemi untuk siswa adalah lebih banyak waktu untuk belajar dirumah, berkumpul dengan keluarga serta menambah soft skill salah satunya belajar membuat aneka makanan dan minuman (07/W/08-12-2020).

Melanjutkan pertanyaan selanjutnya dengan orang yang sama ialah Shintya Febri bagaimana pemahaman siswa dalam mengikuti pendidikan jarak jauh pada era 
pandemi Covid-19? Pembelajaran jarak jauh via online ini bisa berfungsi saling berhubungan sehingga siswa dalam belajar dapat berinteraksi dengan guru lewat PC ataupun smartphone sebagai penghubung dalam pembelajaran. Dalam pemahaman siswa saat melaksanakan daring menyebabkan penurunan dan kurang efektif karena pemahaman siswa yang berbeda-beda sehingga mereka merasa kesulitan saat ada pembelajaran dalam bidang menghafal, menghitung dan praktek. Kemudian saat ada pembelajaran daring gangguan pada jaringan yang kurang stabil menyebabkan informasi yang diterima kurang lengkap (06/W/08-12-2020).

Keinginan guna pembelajaran online pasca Pendemi Covid-19, berharap besar guru berhubungan melalui pendidikan online ialah sehabis keadaan pulih ataupun juga wabah Covid-19 telah berakhir, selain pengajaran di kelas hingga pembelajaran daring senantiasa dapat dilakukan guna melatih keahlian pendidik dan peserta didik pada masa abad 4.0. Pendidikan ini menjadi alternatif pilihan guru dalam mempraktikkan metode dan model proses belajar mengajar. Perihal ini bertujuan buat menambahkan ilmu dan menerapkan pemakaian kemajuan teknologi dengan benar dan tepat. Terdapatnya perlakuan spesial untuk siswa yang kesusahan dalam melaksanakan pendidikan. Sebagaimana dipaparkan salah satu guru di MAN 1 Sragen ialah Ibu Muslimah, S. Pd, M. Pd kalau model pengajaran online baik digunakan namun butuh ditambahkan dengan model pendidikan luar jaringan (luring).

Perihal ini disebabkan bila cuma pengajaran online saja maka kemandirian dan perilaku jujur peserta didik dalam menyelesaikan tugas kurang terkendali. Sehingga baik bila model pendidikan online ini ditindak lanjuti dengan diberi tambahan proses belajar mengajar offline. Terdapat prioritas dalam model-model online yang lebih unggul buat mendukung proses belajar mengajar supaya lebih efisien dan efektif yang sanggup diterima peserta didik secara baik. Pembelajaran online menjadikan pemecahan terbaik buat mendukung kemajuan pembelajaran di rumah dalam keadaan pandemi semacam ini. Kedudukan orang tua di rumah menginginkan bisa maksimal menemani anaknya belajar dirumah. Perihal positif yang bisa didapatkan yaitu peserta didik mempunyai keakraban secara personal dengan orang tua.

\section{Simpulan}

Implikasi riset ini adalah konsekuensi logis dari temuan penelitian. Dari hasil penelitian tersebut di atas dapat dikemukakan implikasinya yakni aktivitas pembelajaran yang umumnya dilaksanakan secara konvensional diganti jadi pendidikan jarak jauh dari rumah. Temuan dilapangan pada riset ini menarangkan kalau proses pendidikan yang dilaksanakan kala ini masih lumayan efektif walaupun disana-sini masih terdapat 
sebagian kendala yang mengusik pendidikan jarak jauh semacam permasalahan interaksi sosial pendidik dengan peserta didik dan ekonomi siswa yang hampir belum siap terdapat kelemahan pendidikan online bagi siswa tidak terpantau dengan baik sepanjang proses pendidikan online. Kelemahan mahalnya biaya kuota dan sinyal internet jadi tantangan tersendiri.

Penerapan pendidikan yang berkualitas akan berimplikasi kepada efektivitas yang baik begitu pula sebaliknya. Kepala madrasah yang berhasil jika mengerti keadaan madrasah dan dapat melalukan pengelolaan dengan manajemen yang baik. Manajemen madrasah yang dilaksanakan sesuai dengan prinsip-prinsip manajemen kaitanya dengan pembelajaran diharapkan akan mampu memberikan pengaruh yang signifikan pada efektivitas siswa. Sehingga keberhasilan penelitian ini diharapkan akan menambah khasanah pengetahuan tentang Manajemen madrasah dalam upaya meningkatkan efektivitas pembelajaran..

\section{DAFTAR PUSTAKA}

Abidin, Z., Hudaya, A., \& Anjani, D. (2020). Research and Development Journal of Education, 1(1), 131-146. https://doi.org/10.30998/rdje.v1i1.7659

Arenggoasih, W., \& Khatibah, I. (2020). Peran Pemerintah sebagai Aktor dalam Jaringan Komunikasi pada Pemberitaan Di Masa Pandemi Covid19 (hlm. Media, Komunikasi dan Informasi di Masa Pandemi Covid-19).

Falahudin, I. (2014). Pemanfaatan Media dalam Pembelajaran. 4, 14.

Fatmawati, Noor, Dewi Liesnoor Setyowati, and Cahyo Budi Utomo. 2018. "Outdoor Study Activity by Utilizing Wonosoco Tourism Village as A Learning Resource of

Social Studies." Journal of Educational Social Studies 7(1): 88-95. https://journal.unnes.ac.id/sju/index.php/jess/article/view/22533.

Firman, F., \& Rahayu, S. (2020). Pembelajaran Online di Tengah Pandemi Covid-19. Indonesian Journal of Educational Science (IJES), 2(2), 81-89. https://doi.org/10.31605/ijes.v2i2.659

Hamidaturrohmah, Tri Mulyani. (2020). Hamidaturrohmah | ELEMENTARY: Islamic Teacher Journal. https://journal.iainkudus.ac.id/index.php/elementary/article/view/7907 
Irwanto \& Zainal Arifin. (2020). Manajer Risiko: Peran Kepala MTS N 1 Kota Yogyakarta Dalam Pembelajaran Daring Masa Pandemi Covid-19 | Irwanto | Tadbir: Jurnal Studi Manajemen Pendidikan. http://journal.iaincurup.ac.id/index.php/JSMPI/article/view/1755

Kurniasari, A., Pribowo, F. S. P., \& Putra, D. A. (2020). Jurnal Review Pendidikan Dasar: Jurnal Kajian Pendidikan dan Hasil Penelitian, 6(3), 246-253. https://doi.org/10.26740/jrpd.v6n3.p246-253

Manaf, A. (2015). Management of Education, 1(1). https://doi.org/10.18592/moe.v1i1.344

Muhaemin, M., \& Mubarok, R. (2020). Upgrade Kompetensi Guru PAI Dalam Merespon Pembelajaran Jarak Jauh Dimasa Pandemi Covid-19. Al-Fikr: Jurnal Pendidikan Islam, 6(2), 75-82. https://doi.org/10.32489/alfikr.v6i2.80

Munir. (2012,. Pembelajaran Jarak Jauh: Berbasis Teknologi Informasi dan Komunikasi . Bandung : Alfabeta

Mu'ayyadah, and Noor Fatmawati. 2021. "Pemanfaatan Teknologi Sebagai Pembelajaran E-Learning Google Classroom Pada Mata Pelajaran IPS.” Asanka: Journal of Social Science and Education 2(1): 31-45. https://jurnal.iainponorogo.ac.id/index.php/asanka/article/view/2364.

Nuriansyah, F. (2020). Jurnal Pendidikan Ekonomi Indonesia, 1(2). https://ejournal.upi.edu/index.php/JPEI/article/view/28346

Prawiyogi, A. G., Purwanugraha, A., Fakhry, G., \& Firmansyah, M. (2020). Efektivitas Pembelajaran Jarak Jauh Terhadap Pembelajaran Siswa di SDIT Cendekia Purwakarta. Jurnal Pendidikan Dasar, 11(1), 94-101.

Rahmawati, I. (2016). Pelatihan dan Pengembangan Pendidikan Jarak Jauh Berbasis Digital Class Platform Edmodo. 411-419. http://repository.ut.ac.id/6536/

Rokhmiyati, S. (2018). Konsep Manajemen Sumber Daya Manusia dalam Kelembagaan Islam. Interdisciplinary Journal of Communication, 3(2), 231-252. https://doi.org/10.18326/inject.v3i2.231-252 
Rokhmiyati, S. (2020). Manajemen kontemporer teori dan aplikasi di era digital. https://isbn.perpusnas.go.id/Account/SearchBuku?searchTxt=Rokhmiyati\&searc hCat=Pengarang

Saifulloh, A. M., \& Darwis, M. (2020). Manajemen Pembelajaran dalam Meningkatkan Efektivitas Proses Belajar Mengajar di Masa Pandemi Covid-19. Bidayatuna: Jurnal Pendidikan Guru Mandrasah Ibtidaiyah, 3(2), 285-312. https://doi.org/10.36835/bidayatuna.v3i2.638

Santani, S. (2020). Utile: Jurnal Kependidikan, 6(2), 168-174. https://doi.org/10.37150/jut.v6i2.990

Shofaul Hikmah. (2020). Efektifitas E-Learning Madrasah dalam Pelaksanaan Pembelajaran Jarak Jauh Masa Pandemi Coronavirus Disease 2019 (Covid-19) di MIN 1 Rembang | Jurnal Edutrained: Jurnal Pendidikan dan Pelatihan. https://bdksemarang.e-journal.id/Ed/article/view/81

Suni, N. S. P. (2020, Februari). Kesiapsiagaan Indonesia Menghadapi Potensi Penyebaran Corona Virus Disease. https://sdip.dpr.go.id/search/detail/category/Info\%20Singkat/id/1033

Supriatna, E. (2020). Wabah Corona Virus Disease Covid 19 Dalam Pandangan Islam. SALAM: Jurnal Sosial dan Budaya Syar-i, 7(6), 555-564. https://doi.org/10.15408/sjsbs.v7i6.15247

Susilo, A., Rumende, C. M., Pitoyo, C. W., Santoso, W. D., Yulianti, M., Herikurniawan, H., Sinto, R., Singh, G., Nainggolan, L., Nelwan, E. J., Chen, L. K., Widhani, A., Wijaya, E., Wicaksana, B., Maksum, M., Annisa, F., Jasirwan, C. O. M., \& Yunihastuti, E. (2020). Coronavirus Disease 2019: Tinjauan Literatur Terkini. Jurnal Penyakit Dalam Indonesia, 7(1), 45. https://doi.org/10.7454/jpdi.v7i1.415

Sutiah, S. (2018). Pengembangan model pembelajaran pendidikan agama Islam. Nizamia Learning Center. http://repository.uin-malang.ac.id/6043/

Tabany, T. I. B. al. (2017). Mendesain model pembelajaran inovatif, progresif, dan kontekstual: Konsep, landasan, dan implementasinya pada Kurikulum 2013 
(Kurikulum Tematik Integratif/KTI) | Perpustakaan FIS. Kencana. //library.fis.uny.ac.id\%2Fopac\%2Findex.php\%3Fp\%3Dshow_detail\%26id\%3D 7681

Wibowo, Y. A., Ronggowulan, L., Abidin, Z., Utomo, A. C., Safriani, E. W., \& Miftakhunisa, Y. (2020). Manajemen Pendidikan, 15(2), 109-125. https://doi.org/10.23917/jmp.v15i2.12618

Yerusalem, M. R., Rochim, A. F., \& Martono, K. T. (2015). Desain dan Implementasi Sistem Pembelajaran Jarak Jauh Di Program Studi Sistem Komputer. Jurnal Teknologi dan Sistem Komputer, 3(4), 481-492. https://doi.org/10.14710/jtsiskom.3.4.2015.481-492

Wawancara

Febri, Shintya. (2020).” Pemahaman Siswa dalam Mengikuti Pembelajaran Jarak Jauh di Masa Pandemi Covid-19”. Hasil Wawancara Pribadi: 8 Desember 2020, MAN 1 Sragen.

Huda, Nurul. (2020). "Efektivitas Pembelajaran Jarak Jauh untuk siswa MAN 1 Sragen". Hasil Wawancara Pribadi: 8 Desember 2020, MAN 1 Sragen.

Khanifudin. (2020). "Metode dan Model Pengajaran Online dalam penerapannya". Hasil Wawancara Pribadi: 21 September 2020, MAN 1 Sragen.

Muslimah. (2020). "Urgensi Pembelajaran online Melalui Pesan Edukatif Pada Masa Pandemi Covid-19”. Hasil Wawancara Pribadi: 9 November 2020, MAN 1 Sragen.

Nurrohmah, Siwi. (2020). "Kendala dalam Pembelajaran Jarak Jauh”. Hasil Wawancara Pribadi: 23 Desember 2020, MAN 1 Sragen.

Salamah, Makrupi T., (2020). "Daya serap dalam pembelajaran jarak jauh". Hasil Wawancara Pribadi: 23 Desember 2020, MAN 1 Sragen.

Sumiran. (2020). "Kerjasama Pihak Sekolah dengan Provider dalam Meningkatkan Layanan Internet di Madrasah". Hasil Wawancara Pribadi: 21 September 2020, MAN 1 Sragen. 
